\title{
A Reflection on the Aesthetic Experience and Its Affection in Moral Education (According of John Dewey)
}

\author{
Ansari Maryam \\ Philosophy of Education, Faculty of Educational sciences and Psychology University of \\ Isfahan, Isfahan, Iran \\ E-mail: ansaryy1260@yahoo.com
}

\begin{abstract}
Nasrabadi Hassanali
Professor of philosophy of Education, Faculty of Educational sciences and Psychology University of Isfahan, Isfahan, Iran
\end{abstract}

\section{Liaghatdar M. Javad}

Professor of curriculum Development, Faculty of Educational sciences and Psychology University of Isfahan, Isfahan, Iran

Bagheri khosro

Professor of Philosophy of Education, Faculty of Educational sciences and Psychology University of Tehran, Tehran, Iran

Received: August 8, 2012 Accepted: September 25, 2012 Published: November 1, 2012 doi:10.5296/jse.v2i4.2212 URL: http://dx.doi.org/10.5296/jse.v2i4.2212

\begin{abstract}
Aesthetic is the branch of philosophy that is discussed about the perception issues including beauty, such as aesthetic experience. John Dewey as a natural philosopher, shared the twentieth century with the possibility of an empirically grounded ethics. There is much to learn from Dewey about how to proceed in an aesthetic experience in quire about morality, so it is important to explore the relation between Dewey's ethics and his aesthetic experience.
\end{abstract}




\section{Macrothink}

This essay with analytical method is an effort to explore this relation. The result showed that Aesthetic experience, response to the demand of feeling in difference situation. Therefore, factors of artistic this experience such as feeling, imagination, compassion are the essential components of morality that complete the experience, understanding, and meaning of morality in the people. Moreover aesthetic experience and moral education are inseparable.

Keywords: John Dewey, Aesthetic experience, Moral education 


\section{Introduction:}

Ethics, according to Noddings (1998), is "a philosophical study of morality", that is, "how we should conduct our lives and, especially, how we should interact with others” (p.136). Moral education might be traced back to the very early period of human society. Great teachers like Socrates, Plato, and Aristotle in the West and Confucius in the East hold that cultivating moral character is the ultimate purpose of education. Dewey, along with many other philosophers, suggests that "all education is moral education" (Boisvert, 1998, p.110) However, educators of ethics differ dramatically in moral education's guiding thoughts. For example, some followers of Aristotle's theory of virtue (1985), some followers of the great thinkers such as Hume, John Stuarts Mill, Spinoza, some are believers of the deontological perspectives of Immanuel Kant (1972) and his modern followers like Lawrence Kohlberg (1981); some believed Wilson's theory of Utilitarianism- the English philosopher- and ultimate many others adopt the pragmatism of John Dewey.

John Dewey as an ethical theorist, presented aesthetics as a very central concern of pragmatism's most active and influential twentieth-century figure (shusterman, 1992, p. 3). Because his philosophy is all what he meticulously worked on in the areas of logic, metaphysics, epistemology and psychology brought to culmination in his understanding of the aesthetic and art (Zeltner, 1975, p. 3).

It has been only since the mid 1970s that scholars in philosophy and education showed increased attention to and positive appreciation of Dewey's important "aesthetic turn". Books by Zeltner (1975), Kupfer (1983), Alexander (1987), and Shusterman (1992/2000), Garrison's (1997), Jackson (1998), Granger (2006) augmented and broadly enhanced Dewey's writhing on education. In fact, with drawing principally from Dewey's books such as "Theory of Valuation (1939), Moral Principles in Education (1909), Experience and nature (1929), Democracy and education (1916), Ethics (1932-1985) and Art as Experience (1932) specially, have finished the stimulus for much of this scholarship. According to John Dewey and other pragmatic philosophers, the artistic and affective factors such as emotion, empathy, imagination, and expression are indispensable components of morality, which complete and consummate people's moral experience, perception, meaning, and understanding (Dewey, 1934).

A few research studies have approached this topic educationally, but they have laid disproportionate emphasis on drama, narrative, literature or music (for instance: Bresler,2002; Deveraux, 2004; Robinson, 2005) (Fordon, 2000). Recently, Scholars and educators have paid attention to the importance of aesthetic experience in moral education besides they have writing qualitative and analytical researches. For example: Uhrmacher (2009), Girod, Twyman \& Wojcikiewicz (2010), Kelly \& Westwood \& Guzman (2010), Nakamara (2009), Kim (2009), You (2008), Stroud (2006), and Elliot (2007), Papas (1997), Fordon (2000) and Noddings (1998) .They researches about aesthetic dimension of Dewey's ethic and moral education. Noddings (1998) described and criticized Dewey's theory of ethics. She believed that Dewey's pragmatic ethics is, like utilitarianism, consequentially. That is, an act can be judged ethically acceptable or unacceptable depending on the consequences it produces ( $\mathrm{p}$. 


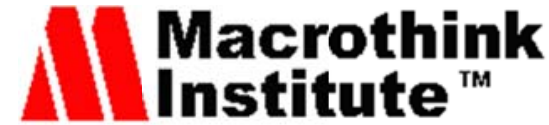

145). Dewey differed with utilitarian, however, on several important issues. First, he thought it was an error to posit one greatest good, even one so obvious and desirable as happiness. Human beings desire a host of goods, and at any given time, happiness may not be the immediate good sought ${ }^{1}$. Second, Dewey objected to the calculation inherent in utilitarianism. Dewey thought we cannot rank utilities and give them stable values. Human events and needs are dynamic, changing events bring new needs and interests (p. 146).

So, the main purpose of the article is to investigate the impact and the role of Dewey's aesthetic experience on education and life. And its approach is analytical and qualitative researches. Therefore it has briefly define aesthetic experience, identified its characteristic, proposed what Dewey might assumed as a "method" in moral education and finally will discuss on the importance and role this experience on education.

\section{Aesthetic experience}

There are obviously difficulties in understanding and defining the concept of aesthetic experience by an analytic approach. "One problem is that aesthetic experience seems to be slippery to have much explanatory power, although it undeniably exists. Another problem is that its attempts to put theory into practice is itself hopelessly impractical, since its revisionary aims are too quixotically ambitious" (Shusterman, 1992, p. 55-58).

Of course Dewey didn't address explicitly his idea on the relationship between aesthetic experience and moral education as a theory. What he mentioned directly about the relationship. However, "is that art is more moral than moralities" (Dewey, 1980, p. 350).

In which the about statement was mention, it may be understood that the art whose main quality is imaginativeness is more moral than moralities or virtues, and hence this may imply that moral education through aesthetic experience can be a more suitable mode of it than its virtue-centered one.

Dewey believed art has experienced criticisms. He wrote "Refused to acknowledge the boundaries set by convention is the source of frequent denunciation of objects of art as immoral. But one of the functions of art is precisely to sap the moralistic timidity that causes the mind of shy away from some materials and refuse to admit them into the dear and purifying light of perceptive consciousness" (Dewey, 1980, p. 189).

Art and esthetic quality that rounds out an experience into completeness and unity as emotional. On the other hand, Dewey (1980) believed the two words "artistic" and esthetic" are signified. Since "artistic" refers primarily to the act of production and "esthetic" to that of perception and enjoyment, the absence of a term designating the two processes taken together is unfortunate (p. 46).

Wong (2007) considered how often humans have aesthetic experience for him, the most deeply engaging experience, how much they are related to the qualitative realm beyond control and rationality and how much important the fact is. 
In discussing the relationship between esthetic and experience, Dewey believed "the esthetic is no intruder in experience from without, whether by way of idle luxury or transcendent ideality, but that it is the clarified and intensified development of traits that belong to every normally complete experience.

\section{Dewey's Moral Education}

Similar to aesthetics, Dewey's moral theory is also pragmatic, unique, and sound. From such rigid abstractions of ethical theories, pragmatic ethics "returns to the ordinary life-experiences of inherently social, embodied, and historically situated beings" (Fesmire, 2002, p. 23).

Dewey's pragmatic ethics is based on consequentiality; that is, an act is judged ethically acceptable or unacceptable according to the consequences it produces. He clearly emphasized ethics in pragmatic approach. First: the role of moral cannot be established as a final cause in moral authority. And second: the ethical needs depend on the moral actor that will lead to moral experience (Papas, 1997, p. 520).

For Dewey, the primary criterion of ethical behavior is willingness to accept responsibility for the full range of anticipated outcomes. Dewey believes that art has a moral function. However, it is not one of moralizing experience- to impart moral principles or massages, but of "teaching" how to be more perceptive-"to remove prejudice, do away with scales that keep the eye from seeing, tear away the veils due to wont and custom, perfect the power to perceive" (1980, p. 328).

According to Cohen, Dewey basically ethicalist. He described philosiophy as a tool of improving community. And perhaps one of the most important reasons that he is affected in education is same. Though scholars have been interested in Dewey's pragmatic aesthetic, many of them have emphasized partially, imagination, moral deliberation, and dramatic rehearsal as the central issues of his ethics.

\section{Components of aesthetic experience}

There are the aesthetic components of Dewey's ethics, namely, qualitative immediacy or qualitative self-awareness, the concepts of inquiry, emotion, sensitiveness, expression, imagination, and Embodiment. Which are the intersections of moral experience and aesthetic experience.

We want to explore some these. The qualitative immediacy is the first characteristic of aesthetic experience. Under certain specific conditions, the humans have a qualitative awareness of their sensations and emotional responses. Such awareness is called feeling. Based on Dewey's perspective our primary relation to reality is a kind of qualitative experience. The Deweyan philosopher, Jim Garrison (1997) claims, "we become what we love," and rephrases that "what we seek to possess soon comes to possess us in thought, feelings and actions.

Dewey considers it as the way people grow. Therefore, educating in order to reach the greatest passion should be the goal of moral education. So, emotion or feelings is essentially 


\section{Macrothink Institute ${ }^{\mathrm{TM}}$}

important in moral education. It is necessary for teachers and educational researchers to acknowledge the existence of the precognitive qualitative background, insightfulness, teacher and students intuitions or the importance of mood and feelings in intuition (kim, 2009, p. 59).

Qualitative experience is an experience which is immediately given and precognitive, but knowable only by the mediating process of inquiry.

Imaginativeness is another characteristic of aesthetic experience. For Dewey" even though all conscious experience has of necessity some degree of imaginative quality" (Dewey, 1980, p. 276). This is because the difference between aesthetic experience and ordinary experience lies in the relative predominance of the imaginative element. Imagination predominates aesthetic experience (Jackson, 1998).

According to Dewey, "every idea is by its nature indicative of a possibility not of present actuality" (p. 251). In other words, for Dewey, imagination, as an important element of aesthetic experience, explores alternative possibilities for actions within a selected context of ongoing activity which enables the search for ideas that can possibly reconstruct the situation, and suggests alternative to our habitual ways of interpreting subjects.

Egan (1997) thinks the imagination involved to all human knowledge and information. Also Alexander (1993) believed: "Through the aesthetic, can the significance of the imagination as the transformation of the world through action. The ontological dimensions of the creation are the intertwining of the actuating and possibly and this is the context in which action makes sense" (p. 209).

Turner's theory of social drama is shown to be compatible with the pragmatist's assumptions regard to experience. Based on turner's extensive anthropological fieldwork, social drawing a theory which can be supplement a pragmatist semiotic through its more explicit and empirically-grounded treatment of institution and culture (Elliott, 2007).

In other words, imagination allows human to grasp infinite transformational possibilities and wisdom, enabling human to think beyond contemporary society's Lows or norms and to realize the potential of his current situation.

Thus, Dewey's discussion of imagination can be summarized in two themes: "empathetic projection" and "creativity tapping a situation's possibilities" (Fesmire, 2003, p. 65).

Through both aspects of imagination operating simultaneous imagination helps us to concretely perceive what is before us in light of what could be. This focuses deliberation concretely on the present. Furthermore, it expands our attention beyond what is immediately experienced (p. 67).

Johnson (1993), influenced by Dewey, even claims that what we need to pursue more than anything else in moral education is "moral imagination". It is because imagination provides both self-knowledge and knowledge of other people, about the imaginative structure of our moral understanding including its values, limitations and blind sports. 


\section{Ml Macrothink}

Journal of Studies in Education

ISSN 2162-6952

2012, Vol. 2, No. 4

Embodiment -one of characterizes of aesthetic education- takes a crucial and complex role in aesthetic experience (Shusterman, 2000). In this view, the "body" refers to the living body which is living, feeling, sentient and purposive body rather than a mere physical corpus of flesh and bones. The rich tradition of this culminates in Dewey's works on naturalistic and aesthetic theories. Dewey provides "probably the most balanced and comprehensive vision among twentieth-century somatic philosophies" (Shusterman, 2008, p. 12).

Dewey (1925) celebrates "body-mind" as an essential unity. He argues that mental life is superimposed on the body by the transcendent power of reason. He claims instead that human mind emerges from the body's more basic physical and psychophysical functions (p. 199). On Dewey's philosophy of body-mind, the Jonson and Alexander's theories were the most influential. Dewey developed "the essential, semantic, organization of Jones while removing some of its troubling dualism and one-sided limitations" (Shusterman, 2008, p. 12).

Now, we have to address the question that what is the role of aesthetic experience in moral education. The answer is that, aesthetic experience contributes to with empathic moral perception, aesthetic moral reasoning and moral action (kim, 2009). According to Hoffman, a leading figure in the field of moral development, feelings of empathy is a positive motive in moral development and the main source of moral motives. Hoffman defines cognitive understanding of another's state of mind, as an effective response that does not necessarily match another's affective state but which it is more appropriate in another's situation than one's own (1984, p. 285; 2000, p. 29).

Dewey (1932-1985) uses the word "sympathy", considering the difference between the words sympathy and empathy, however, what Dewey meant is more like empathy. Dewey (1985) went further: "Sympathy is the animating mold of moral judgment not because its dictates take precedence in action over those of other impulse, but it furnishes the most efficacious intellectual standpoint. It is the tool, par excellence, for resolving and complex situation" (p. 270).

Perception and empathetic connection depend on emotion and imagination. Moral perception is about recognizing and responding thoroughly to the needs, desired, beliefs, values, and behaviors of others. Perceptions become a self- fulfilling prophecy (Rosenthal and Rubin, 1980). "As we become what we love" (Garrison, 1997, p. xiii).

Therefore, teachers should strive to help students perceive their own and their world's best possibilities. Assessing the best possibilities is difficult; however, it requires a great deal of imagination. On this point, imagination is the best instrument of the good and the most important component in the art of prophecy.

So aesthetic experiences helps students to make personal moral judgments in their daily situations. Aesthetic moral judgment is not only a product of reason. It is, instead, based on feelings and imagination, since "things are meaningful by virtue of their relations to other actual or possible qualities, feelings, emotion, images, image schemas, and concepts" (Johnson, 2007, p. 279). 


\section{Discussion}

The ideas as esthetic Experience have their roots in Dewey's works. Although Dewey didn't have a theory of aesthetic education or aesthetic moral education, his interest in the aesthetic dimensions of education has been present since his early work. He claims the necessity of an aesthetic factor in moral education. Dewey states: "I interpret this title to mean a certain phase of all education, rather than a particular group of studies," and includes the following six insightful ideas. First and foremost, Dewey believes that responsiveness, an emotional reaction to ideas and acts, is a necessary factor in moral character. Second, he notes that it is also a necessary element in intellectual training, supplying a delicacy and quickness of recognition in the face of a practical situation. Third, the significance of the aesthetic element is what it trains a natural sensitiveness and susceptibility of the individual toward usefulness in these directions. The individual has a natural tendency to react in an emotional way, but this natural disposition requires training. Fourth, the factors in aesthetic experience that are especially adapted to afford the right training are balance and rhythm. Fifth, the aesthetic element thus should combine freedom of individual expression and appreciation with the factor of law and regularity in what is expressed. It is possible to extend the idea of artistic production to all kinds of work. We can realize that this kind of thought provides the range of the concept of aesthetic experience, which is not limited to artistic activities. Lastly, Dewey points out that modern theory and practice in education have laid relatively too much stress upon volitional training in practical control and intellectual training in the acquisition of information, and too little upon the training of responsiveness (p. 202-203).

Papas (1997) explained Dewey's aesthetic experience as a practical method in moral education. In his viewpoints, there was much to learn from Dewey about how to proceed in an empirical philosophical inquiring in the case of morality.

Dewey considers the "moral function of art". The moral function of art itself is to remove prejudice, do away with the scales that keep the eye from seeing, tear away the veils due to wont and custom, prefect the power to perceive.

According to Dewey, aesthetic experience brings growth for human fully. Because it is including: qualitative immediacy, the concepts of inquiry, emotion, sensitiveness, expression, imagination, and Embodiment. These are the intersections of moral experience and aesthetic experience. So the ultimate goal of moral education is fulfilled in student's moral actions in their daily lives. What does to stir us more to act morally? Aesthetic experience provides such motivation in several ways so that we can act morally beyond understanding and judging morally.

This is possible through desire, because we become what we love. For example, people want their lives to be meaningful. This desire for meaning is so strong that people are sometimes even willing to risk death in their pursuit of meaning and fulfillment.

As the aim of moral education is to desire the good, it is necessary to educate. Then, how can we foster desire for the good? Dewey believes we all have an intuition into a sense of the good. Therefore, what we need is to pay attention to the intuition. Dewey's idea of no "mind" 
versus "body" distinction provides hints for restoring the intuition in our moral education and life.

Aesthetic experience is more than doing and undergoing, acting on the world, and the world acting on us. It also requires a contingent, coherent, and evolving relationship between these elements. In each interaction, there is movement and direction toward some kind of Culmination which its presence is felt through. Therefore, a moral education filled with aesthetic experiences is a more suitable mode of moral education than current cognitive and virtue centered moral education.

Consequently, knowledge acquired through aesthetic experience is a living knowledge, not merely transmitted or memorized rules or virtues. To make personal moral judgment appropriately it should be done in accord with having and using wisdom in various situations. This implication is important, because the goal of moral education for a new century should be to help students develop the ability to make appropriate moral judgments in more various daily situation than ever, beyond merely following moral lows derived by others and pure reason alone.

If what Dewey's method has great procedural power, But Critics of Dewey's ethics object that Dewey makes no distinction between fact and value or between moral and non moral values. All problems can be approached in roughly the same way. Some irritant sense of something's being the matter--leads reflective thinkers to devise hypotheses, explore alternatives, equip themselves as fully as possible with relevant information, test their hypotheses, and evaluate the results. This approach, which is judged so powerful in many situations, may not be adequate for moral problems. (Noddings, 1998, P. 147).

On the other hands, Virginia Held (1993), a feminist, differentiates between moral experience and empirical experience. "Moral experience," for Held, involves more than observable events. It involves feelings. Among other things, "moral experience is the experience of accepting or rejecting moral positions for what we take to be good moral reasons or well-founded moral intuitions or on the basis of what we take to be justifiable moral feelings" (P. 24). Held accepts the distinction most philosophers make: The moral domain, in contrast to other spheres of action, involves what we ought to do, not for mere instrumental reasons but from a deep feeling of conviction. Dewey would almost certainly reply that every domain of life involves in some way what we "ought" to do and that every ought is reasonably construed as an "ought if." However, Dewey's Aesthetic experience, special in education, is still new and so the practical application is very rare and lacks of a strong theoretical structure.

\section{References}

Alexander, T. M. (1987). John Dewey's theory of art, experience, and nature: The horizons of feeling. Albany: State University of New York Press.

Alexander, T. M. (1993). John Dewey and the moral imagination. Transactions of the Charles

S. Pierce Society, 29, 369-400. 
Boisvert, R. D. (1998). John Dewey: Rethinking our time. New York: State University of New York Press.

Dewey, J. (1922). Human Nature and Conduct. New York: Henry Hott \& Company.

Dewey, J. (1909). Moral Principles in Education., New York: Houghton Mifflin Company.

Dewey, J. (1916/1980). Democracy and education. In J. A. Boylston (Ed.), John Dewey: The middle works, 9, Carbondale \& Edwardsville: Southern Illinois University Press.

Dewey, J. (1932/1985). Ethics. In J. A. Boylston (Ed.), John Dewey: The later works, 7, Carbondale and Edwardsville: Southern Illinois University Press.

Dewey, J. (1925/1981). Experience and nature. In J. A. Boylston (Ed.), John Dewey: The later works, 1. Carbondale and Edwardsville: Southern Illinois University Press.

Dewey, J. (1980). Art as experience. Perigee Books: The Berkley Publishing Group. World Wide Web site address is http://www.penguinputnam.com

Dewey, j. (1939). Theory of Valuation. The University of Chicago Press. II(4).

Fesmire, S. (2003). John Dewey and moral imagination: Pragmatism in ethics. Bloomington: Indiana University Press.

Elliot, D. (2007). Living acts of semeiotic: John Dewey’s Model of Esthetic Experience as key to a temporal theory of signs. A Thesis presented to the Faculty of the Graduate School at the University of Missouri-Columbia.

Egan, k. (1997). The educated Mind: How Cognitive Tools Shape our Understanding. Chicago: The University of Chicago Press.

Fordon, A.E. (2000). Arts-Based Educational Studies: An" Adventurous" option to Arts-Based Educational Research.The Journal of Educational Foundations: 14(3), p51. Proudest Educational Journal.

Garrison, J. (1997). Dewey and Eros: wisdom and Desire in the Art of Teaching. New York and London: Teachers College, Columbia University.

Granger, D. A. (2006). John Dewey, Robert Pursing, and the Art of Living: Provisioning Aesthetic Education. New York: Palgrave MacMillan.

Hoffman, M. L. (2000). Empathy and Moral Development: Implications for Caring and Justice. New York: Cambridge University Press.

Held, V. (1993). Feminist Morality. Chicago: University of Chicago Press, p: 25.

Jackson, P.W. (1998). John Dewey and the Lessons of Art. New Haven and London: Yale University Press.

Johnson, M. (1993). Moral imagination: Implication of cognitive science for ethics. Chicago: University of Chicago Press. 


\section{Macrothink}

Journal of Studies in Education

ISSN 2162-6952

2012, Vol. 2, No. 4

Kim, J. (2009). John Dewey, s concept of aesthetic experience: Benefits and application for Moral education. A dissertation of Purdue University for degree of doctor of philosophy. West Lafayette, Indiana.

Kohlberg, L. (1981). The Philosophy of Moral Development. San Francisco: Harper \& Row.

Kupfer, J. (1983). Experience as Art: Aesthetic in Everyday Life. Albany: State University of New York Press.

MOU, B. (2001). Moral Rules and Moral Experience: a comparative analysis of Dewey and Laozi on morality. Asian Philosophy, 11(3).

Nakamara, k. (2009). The Significance of Dewey's aesthetics in art education in the age of globalization.Educational Theory. 59(4). Proquest Educational Journals.

Noddings, N. (1998). Philosophy of education. Boulder, CO: West view Press.

Pappas, G.F. (1997). Dewey's moral theory: experience as method. Transaction of Charles S. Pierce society. XXXIII(3).

Rosenthal, R., \& Rubin, D. (1980). Summarizing 345 studies of Interpersonal Expectancy Effects. In R. Rosental (Ed), Qualitative Assessment of Research Domains: New Directions of Methodology of Social and Behavioral Sciences, 5,79-95. San Francisco: Jossey-Bass.

Stoud, S.R. (2006). John Dewey on Aesthetic Experience and Moral Cultivation, A dissertation submitted the temple university Graduated Board.

Shusterman, R. (1992/2000). Pragmatist Aesthetics: Living Beauty. Rethinking Art. Oxford: Blackwell.

shusterman, R. (2008). Body Consciousness: A Philosophy of Mindfulness and soma esthetics. Cambridge: Cambridge University Press.

Uhrmacher, P.B. (2009). Toward a theory of aesthetic learning experiences. Curriculum Inquiry. 39(5), 613.New York

You, Zh. (2008). The Aesthetic dimensions of Dewey's ethics: A moral imagination model for service- learning in higher education. Dissertation of Purdue University for degree of doctor of philosophy. West Lafayette: Indiana.

Wong, D. (2007). Beyond Control and Rationality: Dewey, Aesthetics, Motivation, and Educative Experiences. New York Teachers College Record, 109(1), 192-220.

Zeltner, P.M. (1975). John Dewey's Aesthetic Philosophy. Amsterdam: B.R. Gruner B.V. 